\title{
Pengembangan Sensor Kimia Berbasis Strip Tes untuk Deteksi Logam Berat Merkuri pada Sampel Produk Jamu
}

\section{(Development of Chemical Sensor-based Strip Test for Mercury Detection on Herbal Medicine Product)}

\author{
Rizqi Amaliyah, Nia Kristiningrum, Indah Purnama Sary \\ Fakultas Farmasi Universitas Jember \\ Jln. Kalimantan 37, Jember 68121 \\ e-mail korespondensi: qiamaliyah@gmail.com
}

\begin{abstract}
The use of plants as a traditional medicine in the modern era is still in high demand. One of the herbs commonly used by Indonesian is analgesic herbal medicine. The safety aspect of herbal medicine should be considered, such as heavy metal contamination. Mercury is the typical heavy metal found in polluting herbal plants. The maximum mercury level allowed in a medicinal preparation has been regulated by $B P O M R I$, as much as $\leq 0.5 \mathrm{ppm}$. A high level of mercury contamination causing toxic effects on the body due to protein precipitation, which inhibits enzyme activity and acts as a corrosive material. A technology that allows the detection of mercury is a chemical sensor. The strip test is optimal if the reagent 1-(2-thiazolyl azo)-2-naphthol (TAN) concentration at $1000 \mathrm{ppm}$ and the sample has been confirmed at $\mathrm{pH}$ 7. The results of the strip test characterization showed that the response time was in the range of minutes 17 to 24, the use time of the test strips for 28 days if stored in room temperature and 29 days if stored at in refrigerator temperature, linearity with $r=0.998, v \times 0=3.96 \%$, $p$-value $=0.00000172, L O D=0.102 \mathrm{ppm}$ and $L O Q=0.306 \mathrm{ppm}$, interference value $<5 \%$, precision with RSD 6.54\%, and accuracy with the value of \% recovery $98.007 \%$. T-test analysis showed $p=$ 0.872, meaning no significant difference between the application of TAN-based test strips with the ICP-AES method.
\end{abstract}

Keywords: Chemical Sensor, Strip test, Hg, TAN, Herbal Medicine (Jamu)

\begin{abstract}
Abstrak
Pemanfaatan tanaman sebagai obat tradisional di era modern masih sangat diminati masyarakat. Salah satu jamu yang diminati oleh masyarakat Indonesia adalah jamu pegal linu. Hal yang harus diperhatikan terkait dengan keamanan jamu yaitu adanya cemaran logam berat, salah satunya merkuri. Kadar maksimal merkuri yang diperbolehkan dalam suatu sediaan jamu telah diatur oleh $\mathrm{BPOM}$ RI yaitu sebesar $\leq 0,5 \mathrm{ppm}$. Jika melebihi batas tersebut ion merkuri dapat menyebabkan efek toksik pada tubuh karena terjadinya proses presipitasi protein dimana menghambat aktivitas enzim dan bertindak sebagai bahan yang korosif. Salah satu teknologi yang memungkinkan untuk mendeteksi merkuri adalah sensor kimia. Sensor Kimia yang digunakan dalam penelitian ini yaitu strip tes. Strip tes berada pada kondisi optimum jika konsentrasi reagen 1-(2-tiazolilazo)-2-naftol (TAN) 1000 ppm dan sampel telah dipastikan dalam kondisi $\mathrm{pH}$ 7. Hasil karakterisasi strip tes menunjukkan bahwa waktu respon berada pada rentang menit ke 17 sampai 24 , waktu pakai strip tes selama 28 hari jika disimpan pada suhu ruang dan 29 hari jika disimpan pada suhu lemari es, linieritas dengan $r=0,998 ; \mathrm{Vx} 0=3,96$ $\%$; p-value $=0,00000172 ; \mathrm{LOD}=0,102 \mathrm{ppm}$ dan LOQ $=0,306 \mathrm{ppm}$; nilai interferensi $<5 \%$; presisi dengan RSD 6,54 \%; dan akurasi dengan nilai \% recovery 98,007 \%. Analisis dengan uji T-test menunjukkan $p=0,872$, yang berarti tidak ada perbedaan signifikan antara aplikasi strip tes berbasis TAN dengan metode ICP-AES.
\end{abstract}

Kata kunci: Sensor Kimia, Strip Tes, Hg, TAN, Jamu 


\section{Pendahuluan}

Pemanfaatan tanaman sebagai obat tradisional (jamu) di era modern masih sangat diminati masyarakat karena efek sampingnya yang lebih sedikit dibandingkan obat dari bahan kimia sintetik meskipun memberikan efek yang terlihat lambat. Salah satu jamu yang diminati oleh masyarakat Indonesia adalah jamu pegal linu. Jamu pegal linu biasa digunakan sebagai obat untuk meredakan nyeri, memperlancar siklus peredaran darah, dan memperkuat sistem imun tubuh. Di dalam jamu obat pegal linu terdapat ekstrak tanaman seperti temulawak, jahe, temu ireng, kunyit, kencur, mengkudu, adas, dan merica [1].

Jamu yang baik harus memperhatikan mutu dan keamanan supaya layak dikonsumsi masyarakat. Salah satu yang harus diperhatikan terkait dengan keamanan jamu yaitu adanya cemaran logam berat. Semua logam berat dapat menimbulkan pengaruh negatif dalam tubuh manusia pada batas konsentrasi tertentu. Salah satu logam berat yang ditemukan mencemari tanaman herbal yaitu merkuri. Kadar maksimal merkuri yang diperbolehkan dalam suatu sediaan jamu telah diatur oleh Badan Pengawasan Obat dan Makanan Republik Indonesia (BPOM RI) yaitu sebesar $\leq 0,5 \mathrm{ppm}$ [2]. Jika melebihi batas tersebut ion merkuri dapat menyebabkan efek toksik pada tubuh karena terjadinya proses presipitasi protein dimana menghambat aktivitas enzim dan bertindak sebagai bahan yang korosif.

Salah satu teknologi yang memungkinkan untuk digunakan sebagai pendeteksi merkuri adalah sensor kimia. Sensor kimia merupakan suatu alat analisis (analytical device) yang berisi reagen kimia (chemical material/reagent) yang dapat bereaksi dengan analit tertentu dalam larutan atau gas sehingga menghasilkan perubahan fisika kimiawi yang dapat dirubah (physicochemical transducer) menjadi sinyal elektrik proporsional [3].

Sensor kimia banyak dikembangkan salah satunya dengan menggunakan sinyal flouresens pada membran sol gel, namun pada metode ini butuh preparasi membran yang sulit, sehingga berdasarkan kelemahan tersebut perlu dikembangkan metode yang lebih praktis lagi seperti strip tes, dimana metode ini dapat digunakan untuk mengetahui konsentrasi bahan maupun analit dalam sampel serta memberikan kesimpulan yang cepat di samping hemat waktu dan biaya.

Metode stip tes mampu mendeteksi kontaminasi merkuri pada produk jamu dengan cara immobilisasi dengan teknik represipitasi dari reagen 1-(2-tiazolilazo)-2-naftol (TAN), dimana fase pendukung dalam strip tes tersebut menggunakan membran ester selulosa. Pemilihan TAN didasarkan pada penelitian terdahulu bahwa TAN memiliki kemampuan berikatan dengan merkuri dengan membentuk kompleks dan memberikan perubahan warna dari merkuri yang berwarna jingga menjadi ungu hingga merah tua [4].

\section{Metode Penelitian Alat dan Bahan}

Alat yang digunakan dalam penelitian ini adalah Inductively Coupled Plasma - Atomic Emission Spectrometry (ICP-AES), komputer, hot plate \& stirrer, hairdryer, set alat gelas, ball pipet, pipet volume (Pyrex®), pipet ukur (Pyrex®), neraca analitik (Sartorius $®$ ), pipet mikro (Gilson $®$ ), labu ukur (Pyrex®), scanner (Scanoscan_cannon $\AA$ ), botol semprot, vial, yellow tip, dan aluminium foil

Bahan yang digunakan dalam penelitian ini adalah Aqua bidestilata/pro injectio (Otsuka/Widatra), membran ester selulosa (Merck - Millipore, Germany®), 1-(2-tiazolilazo)2-naftol (TAN) (Sigma Aldrich $®)$ ), standar logam berat merkuri $\left(\mathrm{Hg}\left(\mathrm{NO}_{3}\right)_{2}\right)$ (Merck®), $\mathrm{NaOH}$ p.a (Merck®), etanol p.a (Merck®), $\mathrm{KH}_{2} \mathrm{PO}_{4}$ p.a (Merck®), sampel jamu pegal linu.

\section{Pembuatan Sensor}

a. Optimasi Konsentrasi Reagen

Dibuat larutan TAN sebesar 2000 ppm, 1000 ppm dan 500 ppm dalam etanol p.a kemudian diimmobilisasi dengan cara sebanyak $100 \mu \mathrm{L}$ larutan TAN dilarutkan ke dalam $10 \mathrm{~mL}$ air yang distirer dengan kecepatan $1000 \mathrm{rpm}$ selama 1 menit. Campuran larutan dispersi yang terbentuk dilewatkan dalam membran ester selulosa dan dikeringkan. 


\section{b. Optimasi Warna (Red/Green/Blue)}

Didasarkan pada nilai koefisien korelasi $(r)$ antara konsentrasi reagen dengan intensitas warna mean red, mean green, mean blue, mean $R G B$ yang memiliki nilai $r$ yang paling mendekati 1.

Pemilihan warna Red/Green/Blue dilakukan dengan membandingkan nilai koefisien korelasi ( $r$ ) masing-masing warna dari konsentrasi reagen 500 ppm, 1000 ppm dan 2000 ppm melalui pembacaan program ImageJ.

c. Optimasi pH Analisis

Sensor TAN yang telah dibuat dicelupkan pada larutan merkuri dengan $\mathrm{pH} 5,6,7,8$ yang dikendalikan menggunakan $\mathrm{pH}$ meter.

d. Teknik Immobilisasi

Reagen TAN didispersikan dalam pelarut etanol p.a sebanyak $100 \mu \mathrm{L}$ ke dalam $10 \mathrm{~mL}$ air pada putaran $1000 \mathrm{rpm}$ selama 1 menit. Kemudian dilewatkan membran ester selulosa sampai dihasilkan lapisan reagen kimia pada bagian permukaan membran.

\section{Pembuatan Larutan Merkuri}

Sebanyak $16,18 \mathrm{mg} \mathrm{Hg}\left(\mathrm{NO}_{3}\right)_{2}$ dimana setara dengan $10 \mathrm{mg} \mathrm{Hg}$ dicampur dan dilarutkan dalam $10 \mathrm{~mL}$ aquabidest. Lalu diencerkan menjadi beberapa konsentrasi, yaitu $5 \mathrm{ppm}, 0,5$ ppm, dan 0,1 ppm.

\section{Pembuatan Seri Larutan Dapar Fosfat}

Sejumlah tertentu $\mathrm{NaOH} 0,1 \mathrm{~N}$ dicampur dengan $\mathrm{KH}_{2} \mathrm{PO}_{4} \quad 0,1 \mathrm{~N}$ kemudian diatur $\mathrm{pH}$ dengan $\mathrm{pH}$ meter digital untuk mendapat seri larutan dapar fosfat pada rentang $\mathrm{pH} 5-8$.

\section{Karakterisasi Sensor}

\section{a. Waktu Respon}

Penentuan waktu respon dilakukan dengan cara mereaksikan reagen TAN yang telah diimmobilisasi ke dalam membran ester selulosa pada merkuri dan dilakukan scanning dengan jangka waktu tertentu. Kemudian hasilnya dianalisis menggunakan pembacaan pada program imageJ dengan melihat nilai $\Delta$ mean red untuk mendapatkan waktu respon yang optimum.

\section{b. Waktu Pakai}

Penentuan waktu pakai dari strip tes dilakukan dengan membungkus strip tes menggunakan aluminium foil dan disimpan pada plastic clip beserta penyerap kelembaban berupa silica gel. Tahapan ini dilakukan pada dua kondisi berbeda, yaitu suhu ruang $25^{\circ} \mathrm{C}$ dan suhu lemari es 2 - $8^{\circ} \mathrm{C}$. Penentuan waktu pakai dilakukan dengan mengamati respon warna pada strip tes saat diaplikasikan ke dalam konsentrasi logam merkuri setiap hari.

\section{c. Linieritas}

Penentuan nilai linieritas dilakukan dengan menggunakan imageJ dengan $\Delta$ mean RGB yang linier. Tahapannya yaitu dengan mencelupkan strip tes ke dalam variasi rentang konsentrasi 25 - $200 \%$ standar merkuri 0,5 ppm. Parameter yang digunakan untuk mengetahui hubungan linieritas adalah koefisien korelasi ( $r$ ) pada analisis regresi $y=a+b x$. Hasil dapat dikatakan linier apabila nilai $r$ mendekati 1 [5].

d. Batas Deteksi (LOD) dan Batas Kuantitasi (LOQ)

Dibuat seri konsentrasi larutan standar logam berat di bawah konsentrasi terkecil dari rentang pengujian linieritas. Program Validation Method of Analysis digunakan untuk menganalisis data yang diperoleh sehingga didapatkan kurva linieritas konsentrasi yang sebanding dengan nilai $\triangle$ mean RGB dan dihitung nilai LOD dan LOQnya [5].

\section{e. Selektivitas}

Pada penelitian ini sampel yang berisi merkuri digunakan sebagai standard untuk membandingkan dengan sampel berisi merkuri dengan campuran timbal dan merkuri dengan campuran kadmium. Masing-masing sampel diberi perlakuan 1:1, 1:10 dan 1:100 selanjutnya dihitung nilai interferensinya [5].

Penentuan selektivitas dilakukan untuk memperoleh hasil perbandingan $\triangle$ mean RGB standar merkuri yang telah diberi komponen penggangu seperti timbal dan kadmium dengan tanpa diberi pengganggu. Metode dikatakan selektif apabila \%interferensi $<5 \%$. Perhitungan 
nilai selektifitas dapat dilihat pada rumus di bawah ini.

$\%$ Selektivitas $=\frac{(\Delta \text { mean } R G B \text { uji }-\Delta \text { mean } R G B \text { standar })}{\Delta \text { mean } R G B \text { standar }} \times 100 \%$.

f. Presisi

Penentuan presisi dapat ditentukan dengan menghitung nilai Standar Deviasi Relatif (RSD) dari 6 kali pengukuran strip tes yang berbeda.

\section{g. Akurasi}

Tahapan ini dilakukan dengan cara menimbang $0,5 \mathrm{~g}$ sampel plasebo dengan tiga macam konsentrasi yaitu $80 \%, 100 \%$, dan $120 \%$ lalu ditambahkan standar $\mathrm{Hg}$ dan dimasukkan ke dalam labu ukur $10 \mathrm{~mL}$ kemudian ditambahkan aquabidest sampai tanda batas. Selanjutnya strip tes dicelupkan ke dalam larutan campuran tersebut dan diamati perubahan warna yang terjadi. Nilai $\triangle$ mean RGB yang diperoleh dimasukkan ke dalam persamaan regresi sehingga didapatkan konsentrasi merkuri dalam sampel. Selanjutnya ditentukan nilai \%recovery dengan membandingkan massa logam berat yang diperoleh dengan massa logam berat secara teoritis [5].

\section{Pembuatan Strip Tes}

Bagian pegangan digunakan mika plastik yang tidak dapat menyerap cairan dengan ukuran $7,5 \mathrm{~cm} \times 0,5 \mathrm{~cm}$, dan area deteksi kandungan logam digunakan membran ester selulosa berbentuk lingkaran dengan diameter 0,5 $0,8 \mathrm{~cm}$. Area deteksi direkatkan pada pegangan hingga seluruh permukaan bagian belakang strip tes tertutup sempurna.

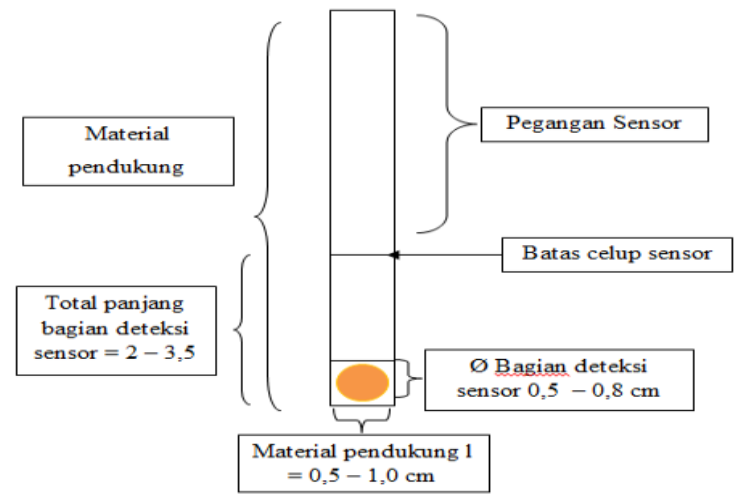

Gambar 1 Desain Strip Test

\section{Aplikasi Strip Tes pada Sampel Jamu Pegal} Linu

Sampel yang digunakan yakni produk jamu di pasaran, mempunyai nomor ijin edar yang tercantum dalam kemasan, dan klaim untuk jamu pegal linu yang sudah terdaftar di BPOM maupun yang tidak terdaftar di BPOM.

\section{Penetapan Kadar Merkuri pada Jamu Pegal Linu dengan Metode ICP-AES}

Ditimbang $1 \mathrm{~g}$ sampel jamu kemudian dimasukkan dalam erlenmeyer. Tambahkan 20 $\mathrm{mL} \mathrm{HNO}: \mathrm{HClO}_{4}(2: 1)$ dan didestruksi di hot plate hingga jernih. Lalu tambahkan $10 \mathrm{~mL}$ air suling, lalu saring di labu $25 \mathrm{~mL}$ dan dilakukan penambahan air suling kembali hingga tanda batas. Pada tahap terakhir dilakukan pembacaan dengan alat ICP-AES dengan mengukur nilai absorbansi dari sampel pada panjang gelombang pengukuran $200 \mathrm{~nm}$.

\section{Hasil Penelitian}

\section{Optimasi Kondisi Analisis}

a. Optimasi Konsentrasi Reagen

Pemilihan konsentrasi reagen didasarkan pada intensitas perubahan warna yang diberikan reagen TAN setelah diimmobilisasi. Hasil optimasi dapat dilihat pada table 1.

Tabel 1. Optimasi Konsentrasi Reagen

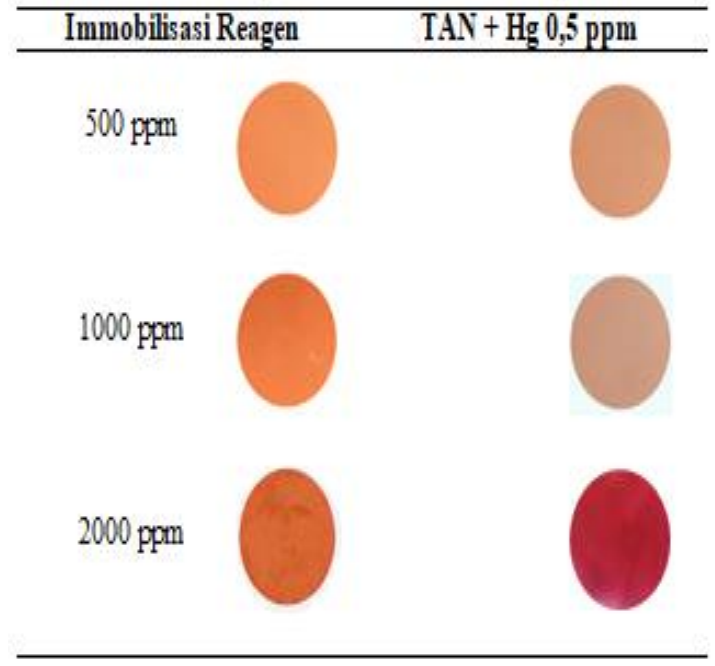


b. Optimasi Pemilihan Warna Red/Green/B/ue

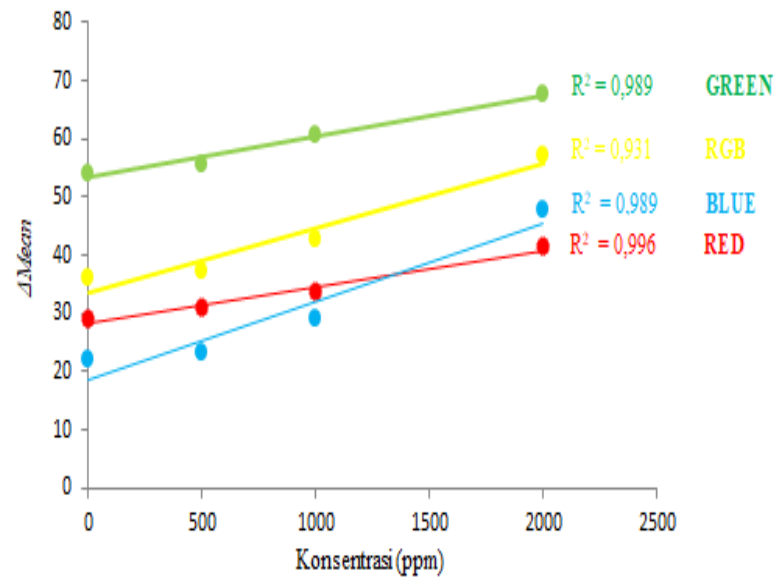

Gambar 2 Pembacaan Warna Menggunakan ImageJ

Gambar 2 menunjukkan pembacaan image $J$ di atas maka warna yang terpilih yaitu red dengan koefisien korelasi yang paling mendekati 1 yaitu 0,996 .

c. Optimasi pH Analisis

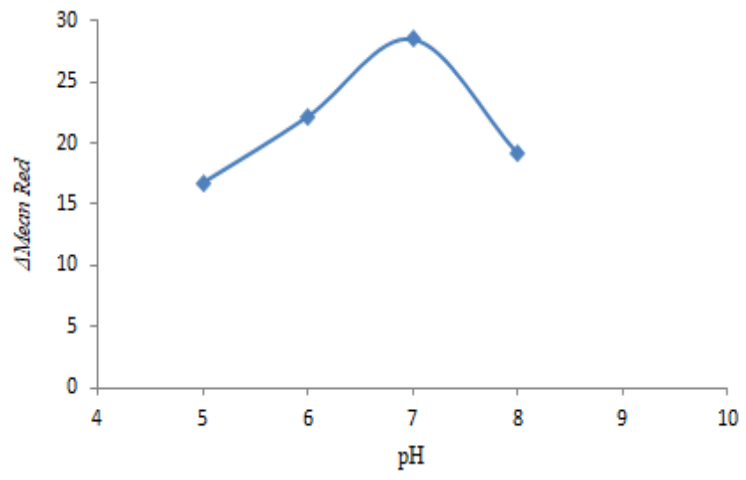

Gambar 3. Kondisi Optimum pH

Berdasarkan gambar di atas dapat disimpulkan bahwa $\mathrm{pH}$ berpengaruh terhadap kerja strip tes dengan $\mathrm{pH}$ netral yaitu 7 , karena $\mathrm{pH} 7$ memiliki nilai $\Delta$ mean red paling tinggi yaitu 28,494 .

\section{Karakteristik Sensor}

a. Waktu Respon

Hasil pengukuran waktu respon ditunjukkan pada gambar 4.

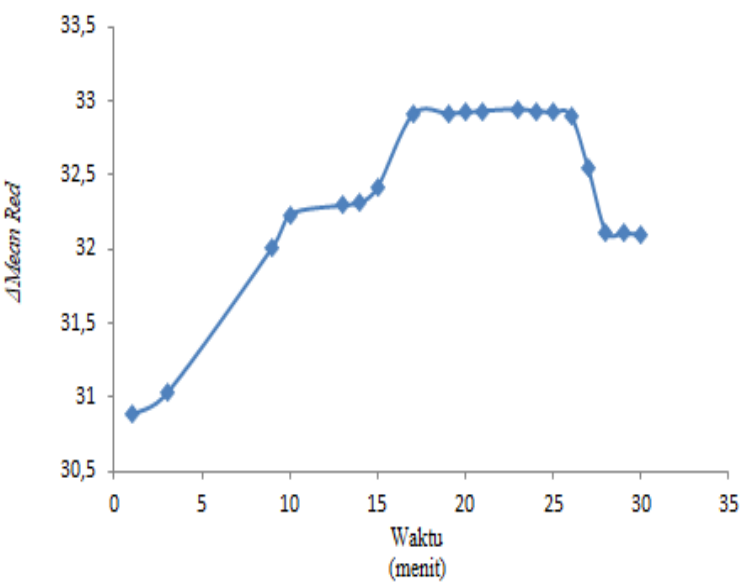

Gambar 4 Grafik Waktu Respon

b. Waktu Pakai

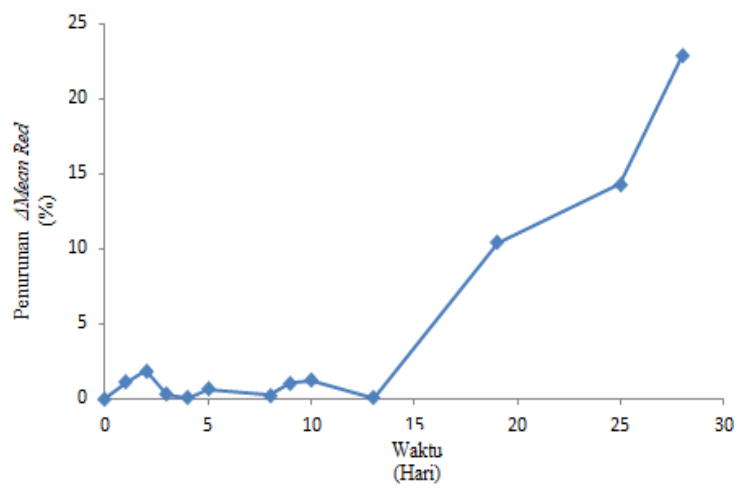

Gambar 5 Waktu Pakai Sensor Pada Suhu Ruang

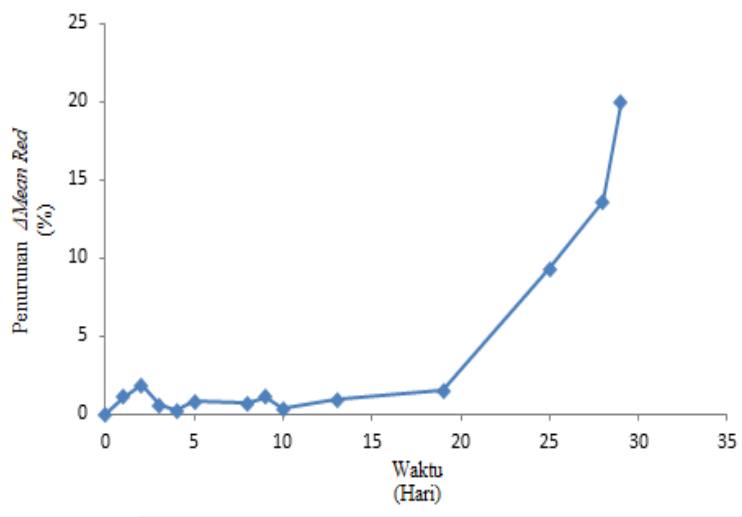

Gambar 6 Waktu Pakai Sensor Pada Suhu Lemari Es 
c. Linieritas

Dalam penelitian ini uji linieritas dilakukan melalui 6 konsentrasi standar merkuri pada rentang 0,1 ppm - $1 \mathrm{ppm}$. Konsentrasi uji terpilih yaitu, 0,1 ppm, 0,3 ppm, 0,4 ppm, 0,5 ppm, 0,6 ppm, dan $1 \mathrm{ppm}$.

Tabel 2 Hasil Uji Linieritas

\begin{tabular}{ccc}
\hline $\begin{array}{c}\text { Konsentrasi } \\
\text { Analit } \\
\text { (ppm) }\end{array}$ & $\begin{array}{c}\Delta \text { Mean } \\
\text { Red }\end{array}$ & SD (\%) \\
\hline 0,1 & 41,003 & 0,578 \\
0,2 & 42,940 & 0,854 \\
0,3 & 44,526 & 0,542 \\
0,4 & 45,742 & 0,802 \\
0,7 & 50,384 & 0,483 \\
1 & 54,403 & 0,050 \\
\hline
\end{tabular}

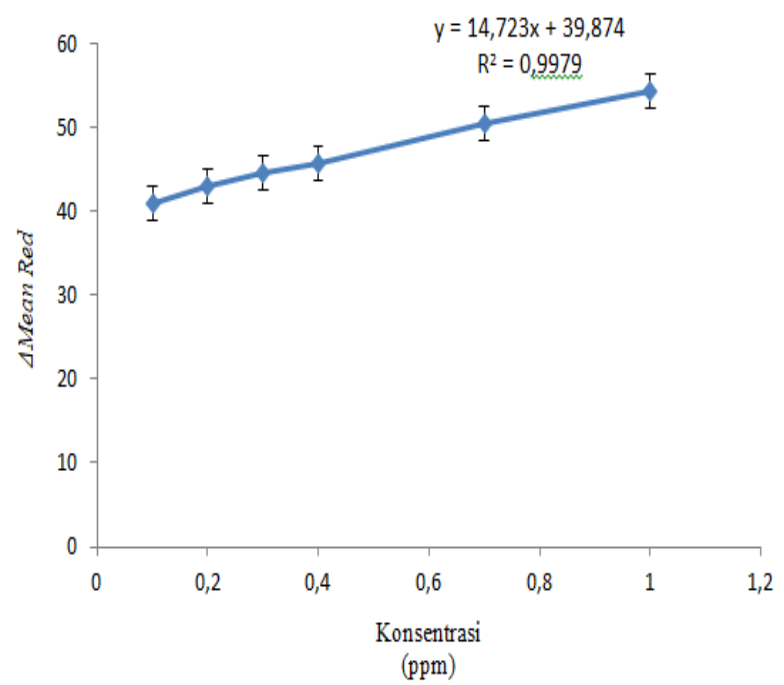

Gambar 7 Grafik Hubungan Antara Konsentrasi dengan $\Delta$ Mean Red

Berdasarkan hasil di atas diperoleh nilai koefisien korelasi ( $r$ ) 0,998 dan analisis regresi y $=14,723 x+39,874$. Nilai $r$ tersebut memenuhi parameter adanya hubungan linier dengan nilai koefisien korelasi mendekati 1 . Artinya hubungan antara konsentrasi dengan $\Delta$ mean red linieritas di atas memiliki korelasi yang positif, hal ini dikarenakan kenaikan atau penurunan konsentrasi yang berbanding lurus dengan $\Delta$ mean red. Nilai $r$ di atas diikuti dengan nilai $p$ value 0,00000172 dan $\mathrm{V} \times 03,96 \%$. Nilai tersebut memenuhi parameter dengan syarat nilai $p$-value $\leq 0,01$ dan $\mathrm{Vx} 0<5 \%$. Nilai $p$-value menunjukkan kesalahan hasil perhitungan merkuri yang didapat peneliti, dengan angka 0,0000017 maka hasil peneliti dapat diterima dan dianggap signifikan.

\section{d. LOD dan LOQ}

Tabel 3 Konsentrasi Standar Merkuri dan $\Delta$ Mean Red

\begin{tabular}{cc}
\hline $\begin{array}{c}\text { Konsentrasi Analit } \\
\text { (ppm) }\end{array}$ & sMean Red \\
\hline 0,1 & 41,003 \\
0,2 & 42,940 \\
0,3 & 44,526 \\
0,4 & 45,742 \\
0,7 & 50,384 \\
1 & 54,403 \\
\hline
\end{tabular}

Berdasarkan hasil analisis dengan VMA didapatkan nilai LOD dan LOQ sebagai berikut: DL value (LOD) : 0,102 ppm $Q L$ value (LOQ) : 0,306 ppm

Dari hasil diatas dapat dinyatakan bahwa nilai batas deteksi analit yaitu 0,102 ppm yang artinya jumlah kadar merkuri terkecil yang masih bisa dideteksi tetapi belum tentu bisa terukur oleh strip tes di dalam sampel jamu yakni 0,102 ppm. Sedangkan nilai batas kuantitasi yaitu 0,306 ppm, dapat diartikan bahwa batas nilai konsentrasi terendah merkuri yang dapat diukur pasti oleh strip tes yakni 0,306 ppm.

e. Selektivitas

Tabel 4 Perbandingan Penambahan Interferensi dan Nilai \% Interferensi

\begin{tabular}{ccc}
\hline $\begin{array}{c}\text { Penambahan } \\
\text { Interferensi }\end{array}$ & $\begin{array}{c}\text { Perbandingan } \\
\text { Konsentrasi } \\
(\mathrm{ppm})\end{array}$ & $\begin{array}{c}\text { Interferensi } \\
(\%)\end{array}$
\end{tabular}

Standard $\mathrm{Hg}$

0

$\begin{array}{ccc}\mathrm{Pb}(1: 1) & 0,4 \mathrm{Hg}: 0,4 \mathrm{~Pb} & 2,67 \\ \mathrm{~Pb}(1: 10) & 0,4 \mathrm{Hg}: 4 \mathrm{~Pb} & 2,36 \\ & 0,4 \mathrm{Hg}: 40 \mathrm{~Pb} & 1,58\end{array}$


$\mathrm{Pb}(1: 100)$

$\begin{array}{ccc}\text { Cd }(1: 1) & 0,4 \mathrm{Hg}: 0,4 \mathrm{Cd} & 1,29 \\ \mathrm{Cd}(1: 10) & 0,4 \mathrm{Hg}: 4 \mathrm{Cd} & 0,94 \\ \text { Cd }(1: 100) & 0,4 \mathrm{Hg}: 40 \mathrm{Cd} & 4,55\end{array}$

Dari hasil uji selektivitas diperoleh grafik antara $\Delta$ mean red dengan interferensi masingmasing penambahan analit pengganggu. Dapat disimpulkan bahwa sensor memenuhi parameter adanya selektivitas, yaitu $<5 \%$ yang artinya sensor selektif untuk pengujian logam berat merkuri dan meskipun terdapat logam berat pengganggu lainnya seperti $\mathrm{Pb}$ dan $\mathrm{Cd}$ tidak akan mempengaruhi hasil yang diberikan sensor.

f. Presisi

Tabel 5 Nilai RSD Ke-3 Hari yang Berbeda

\begin{tabular}{cc}
\hline Presisi Hari Ke- & Nilai RSD (\%) \\
\hline 1 & 6,93 \\
2 & 6,03 \\
3 & 6,67 \\
\hline Rata-Rata RSD & $6,54 \%$ \\
\hline
\end{tabular}

Berdasarkan hasil di atas diperoleh ratarata RSD dari ke-3 hari yang berbeda sebesar $6,54 \%$. Presisi menunjukkan kedekatan nilai satu dengan yang lainnya pada hari yang berbeda, nilai RSD beruturut diperoleh $6,93 \% ; 6,03 \%$; $6,67 \%$; semakin dekat nilai RSD hari pertama sampai hari ke tiga maka semakin baik pula nilai RSD yang diperoleh. Sehingga dapat disimpulkan bahwa nilai presisi memiliki kedekatan atau keseragaman pengulangan nilai yang baik. Hasil yang didapat dari penelitian ini menunjukkan kesesuaian dengan persyaratan RSD yaitu $\leq 7,3 \%[6]$.

\section{g. Akurasi}

Penelitian ini dilakukan 3 kali replikasi dan dihitung \%recoverynya dengan menggunakan tiga macam konsentrasi yaitu $80 \%, 100 \%$ dan $120 \%$ dari kadar analit. Konsentrasi yang dibuat antara lain 0,04 ppm (80\%), 0,5 ppm (100\%) dan $0,6 \mathrm{ppm}(120 \%)$.

e-Journal Pustaka Kesehatan, vol. 9 (no. 1), Januari 2021
Tabel 6 Hasil Rata-Rata \% Recovery

\begin{tabular}{ccccc}
\hline $\begin{array}{c}\text { Penambahan } \\
\text { Analit } \\
(\%)\end{array}$ & $\%$ Recovery & Mean & SD & RSD \\
\hline 80 & 96,263 & & & \\
100 & 102,596 & $98,007 \%$ & 4,018 & $4,09 \%$ \\
120 & 95,163 & & & \\
\hline
\end{tabular}

Dari data diatas diperoleh hasil \% recovery sama dengan 98,007\%. Akurasi menunjukkan ketepatan dan kemiripan nilai antara pengukuran dengan analit yang ditambahkan, semakin dekat nilai antara pengukuran dan analit maka nilai akurasi yang diperoleh semakin baik $\mathrm{Hal}$ ini dapat dibuktikan dengan hasil \% recovery $80-120 \%$ memiliki rata-rata $98,007 \%$ yang mana hasil ini memenuhi parameter kriteria penerimaan akurasi [6].

\section{Pembuatan Strip Tes}

Strip tes yang akan digunakan untuk mendeteksi kandungan logam merkuri terdiri dari dua bagian yaitu bagian pegangan dan bagian deteksi, bagian pegangan strip tes digunakan bahan yang tahan terhadap cairan dengan ukuran $6,5 \mathrm{~cm} \times 0,4 \mathrm{~cm}$ yang terbuat dari mika plastik, sedangkan bagian deteksi untuk logam digunakan bahan yang terbuat dari membran ester selulosa berbentuk lingkaran dengan diameter 0,5-0,8 cm. Bagian deteksi direkatkan menggunakan doubletape pada pegangan hingga merekat sempurna.

\section{Penetapan Kadar Merkuri dalam Jamu Pegal Linu Menggunakan Strip Tes}

Tahap terakhir penelitian ini setelah dilakukan validasi metode analisis adalah penerapan metode analisis strip tes terhadap sampel jamu lain yakni NRL, YST, SBT dan IPL. Untuk mengetahui konsentrasi merkuri dalam jamu, dilakukan penetapan kadar sampel jamu dengan strip tes yang telah tervalidasi.

Tabel 7 Penetapan Kadar Sampel Jamu

\begin{tabular}{cc}
\hline Nama Sampel & $\begin{array}{c}\text { Konsentrasi Hasil } \\
\text { Percobaan }(\mathbf{p p m})\end{array}$ \\
\hline IPL & 0,315 \\
NRL & $-0,155$ (Tidak terdeteksi
\end{tabular}

$\mathrm{Hg})$ 


\begin{tabular}{ll} 
SBT & $\begin{array}{l}-0,006 \text { (Tidak terdeteksi } \\
\mathrm{Hg})\end{array}$ \\
YST & 0,017 \\
\hline
\end{tabular}

\section{Analisa Data}

Pada penelitian ini dilakukan analisis data dengan metode uji $\mathrm{T}$ berpasangan (Paired Sampe T-Test) untuk mengetahui apakah sensor kimia yang digunakan dapat diterapkan atau tidak. Analisis data T-test diperoleh dari perbandingan penentuan kadar menggunakan strip tes dengan ICP-AES.

Tabel 8 Perbandingan Penetapan Kadar Menggunakan Strip Tes dan ICP-AES

\begin{tabular}{cccc}
\hline $\begin{array}{c}\text { Nama } \\
\text { Sampel }\end{array}$ & $\begin{array}{c}\text { Strip Tes } \\
\text { (ppm) }\end{array}$ & $\begin{array}{c}\text { ICP- } \\
\text { AES } \\
(\mathbf{p p m})\end{array}$ & $\begin{array}{c}\text { Hasil } \\
\text { Analisa } \\
\text { T-test }\end{array}$ \\
\hline IPL & 0,315 & 0,048 & \\
YST & 0,017 & 0,016 & 0,498 \\
\hline
\end{tabular}

Kemudian dilakukan uji T-test dari hasil pembacaan kedua metode di atas. Hasil uji T-test diperoleh nilai $P(T \leq t)$ sebesar 0,498 sehingga dapat dikatakan jika hasil nilai T-test $>0,05$ maka data hasil perbandingan tidak menunjukkan perbedaan yang signifikan.

\section{Pembahasan}

Penelitian diawali dengan mencari optimasi kondisi analisis, seperti hasil pada table 1. Perubahan warna yang paling optimum (perubahan warna dari jingga ke merah keunguan) ditunjukkan oleh konsentrasi 1000 ppm. Sedangkan pada konsentrasi 500 ppm perubahan warna yang dihasilkan berupa warna jingga tua, dan pada konsentrasi 2000 ppm perubahan warna yang dihasilkan yaitu merah kecoklatan. Hal ini disebabkan karena pada konsentrasi 2000 ppm reagen TAN terlalu pekat sehingga perubahan warna yang terjadi lebih gelap tidak seperti yang diharapkan, dan pada konsentrasi 500 ppm tidak menunjukkan perubahan warna yang signifikan.
Selain itu, optimasi juga dilakukan terhadap pemilihan warna. Berdasarkan pembacaan imageJ pada gambar 1 maka warna yang terpilih yaitu red dengan koefisien korelasi yang paling mendekati 1 yaitu 0,996 . Hal ini berkaitan dengan perubahan warna yang diinginkan dalam penelitian yaitu merah keunguan. Pada optimasi $\mathrm{pH}$, yang berpengaruh terhadap kerja strip tes adalah $\mathrm{pH}$ netral yaitu 7 , karena $\mathrm{pH} 7$ memiliki nilai $\Delta$ mean red paling tinggi yaitu 28,494.

Karakteristik sensor diukur dnegan beberapa indikator. Pembacaan sensor dengan imageJ dimulai pada menit ke-17 hingga menit ke-24. Setelah itu sensor sudah mengalami penurunan waktu respon. Jadi, apabila dilakukan pembacaan setelah menit ke-24 maka hasilnya sudah tidak valid atau tidak dapat dipercaya. Hasil karakteristik sensor juga menunjukkan sensor hanya dapat digunakan selama 28 hari jika disimpan pada suhu ruang $\left(25^{\circ} \mathrm{C}\right)$ dan 29 hari jika disimpan pada suhu lemari es $\left(2-8^{\circ} \mathrm{C}\right)$, selebihnya sensor akan mengalami penurunan kualitas dan tidak dapat digunakan kembali karena hasil yang diperoleh tidak valid.

Mengacu pada Gambar 7 semakin tinggi nilai konsentrasi standar merkuri maka semakin tinggi pula nilai $\Delta$ mean red nya, hal tersebut disebabkan oleh perubahan warna yang diberikan konsentrasi yang lebih tinggi menghasilkan intensitas warna lebih tinggi pula yaitu merah keunguan.

Strip tes yang akan digunakan untuk mendeteksi kandungan logam merkuri terdiri dari dua bagian yaitu bagian pegangan dan bagian deteksi, bagian pegangan strip tes digunakan bahan yang tahan terhadap cairan dengan ukuran $6,5 \mathrm{~cm} \times 0,4 \mathrm{~cm}$ yang terbuat dari mika plastik, sedangkan bagian deteksi untuk logam digunakan bahan yang terbuat dari membran ester selulosa berbentuk lingkaran dengan diameter $0,5-0,8 \mathrm{~cm}$.

Tahap akhir penelitian ini adalah validasi hasil pengukuran. Hasil penelitian terlihat bahwa konsentrasi merkuri dalam sampel jamu IPL, NRL, SBT dan YST berturut-turut sebesar 0,315; 0,$155 ;-0,006 ; 0,017$. Nilai minus (-) pada pengujian diatas menunjukkan bahwa sampel 
jamu tersebut tidak mengandung merkuri di dalamnya. Dan dilanjutkan dengan analisis data. Berdasarkan hasil tersebut dapat disimpulkan bahwa hasil penetapan kadar dengan menggunakan strip tes dan ICP-AES tidak memiliki perbedaan, sehingga strip tes ini dapat diterapkan dalam pengujian kadar logam berat merkuri pada produk jamu.

\section{Simpulan dan Saran}

Berdasarkan penelitian yang dilakukan maka dapat disimpulkan bahwa engembangan sensor kimia berbasis strip tes untuk deteksi logam berat merkuri $(\mathrm{Hg})$ berada pada kondisi optimum konsentrasi reagen TAN 1000 ppm dan sampel dipastikan dalam kondisi $\mathrm{pH} 7$.

Hasil karakterisasi strip tes menunjukkan bahwa waktu respon berada pada rentang menit ke 17 sampai 24, waktu pakai strip tes selama 28 hari jika disimpan pada suhu ruang dan 29 hari jika disimpan pada suhu lemari es. Linieritas dengan $r=0,998 ; \mathrm{VxO}=3,96 \% ; p$-value $=$ 0,00000172 , $L O D=0,102 \mathrm{ppm}$ dan $\mathrm{LOQ}=0,306$ ppm, nilai interferensi kurang dari $5 \%$, presisi dengan RSD 6,54 \%, dan akurasi dengan nilai \% recovery $98,007 \%$. Analisis data menunjukan bahwa data hasil perbandingan antara aplikasi strip tes berbasis TAN dengan metode Inductively Coupled Plasma-Atomic Emission Spectrometry (ICP-AES) tidak menunjukan perbedaan yang signifikan.

\section{Daftar Pustaka}

[1] Husna OL, dan Hanifah A. 2015. Analisa kandungan logam berat timbal, kadmium, dan merkuri dalan produk jamu pegal linu yang beredar di kota pekanbaru. Jom Fmipa. 2(1):130-135.

[2] BPOMRI. 2017. Statistik Semua Produk BPOM.

[3] Kuswandi B. 2010. Sensor kimia: teori, praktek dan aplikasi. Jember: Jember University Press.

[4] Kuswandi B, Vaughan AA, dan Narayanaswamy R. 2001. Simple regression model using an optode for the simultaneous determination of zinc and cadmium mixtures in aqueous samples. Analytical sciences : the international journal of the Japan Society for Analytical Chemistry. 17(1) : 181-186

[5] Harmita. 2004. Petunjuk Pelaksanaan Validasi Metode dan Cara Perhitungannya, Maj Ilmu Kefarmasian, 1(3):127.

[6] Huber L. 2007. Validation and Qualification in Analytical Laboratories, Second Edition. Edisi 2nd. Boca Raton: CRC Press. 